\title{
Research on the Mode of Innovation and Cultivation of Entrepreneurial Talents in Colleges and Universities
}

\author{
Yang LIU ${ }^{1, a}$, Yi-He ZHANG ${ }^{1, b}$, Chen ZHANG ${ }^{1, c}$, Ze-Xuan YIN ${ }^{1}$, Chun-Ping \\ $W^{1}$,Chun-Yan QIU ${ }^{1, d,{ }^{*}}$, Chi-Jun ZHANG ${ }^{1}$, Ren SONG ${ }^{2}$, Yan MA ${ }^{1}$ and Xiang \\ $\mathrm{LI}^{1}$ \\ ${ }^{1}$ School of management science and information engineering, Jilin University of Finance and \\ Economics, Changchun, 130117, China \\ ${ }^{2}$ Information Management Center, Jilin University of Finance and Economics, Changchun, 130117, \\ China \\ a email: 7923759@qq.com, b email: 1120013567@qq.com \\ cemail:2243829592@qq.com, ${ }^{d}$ email: 81692002@qq.com \\ *Corresponding author
}

Keywords: Innovation, Talents training, Entrepreneurship education.

\begin{abstract}
The training model of innovation and entrepreneurship in colleges and universities is to train innovative and entrepreneurial talents as the goal. Through reforming the teaching contents and teaching methods of the two subjects of the theoretical teaching system and the practical curriculum system, driven by college students' innovation and entrepreneurship programs and innovation and entrepreneurship discipline competitions. Vigorously promote innovation and entrepreneurship training and innovation and entrepreneurship project incubation two support platform for innovation and entrepreneurship training mode. Strive to train enterprises and society urgently needed innovative, practical, complex talents.
\end{abstract}

\section{Introduction}

With the educational development and teaching reform in higher education institutions, innovative and entrepreneurial-oriented personnel training mode centered on innovation and entrepreneurship has drawn widespread attention from the state, society and universities. The so-called innovative entrepreneurial talent, refers to the innovative spirit and entrepreneurial talent. Talent resources are the primary resources and also the most active and active factor in innovation activities. Whether innovation and entrepreneurship can become an important support force for national innovation-driven development lies in whether we can cultivate innovative entrepreneurs with scientific knowledge, technical skills, innovative spirit and entrepreneurial ability[1]. As an important combination point of the first resource of talents, the first driving force of science and technology and innovation, colleges and universities not only serve as an important base for cultivating high-level innovative entrepreneurship but also as an important source of high-level scientific research and high-quality innovation. To promote public entrepreneurship, innovation and training of outstanding innovation and entrepreneurship talent, play an important role in supporting and leading[2]. 


\section{University Innovation and Entrepreneurship Training System Model}

The training system of innovation and entrepreneurship in colleges and universities is based on the training of innovative and pioneering talents, in order to improve college students' interdisciplinary capabilities, practical ability and ability of innovation and entrepreneurship, training enterprises and socially needed innovative, practical, complex talents as the basic personnel training mode.

The training system of innovation and entrepreneurship in colleges and universities carries out modular division of cultivation of innovative and pioneering talents, including the establishment of module of internal courses and the support of system platform in colleges and universities. Based on the training of innovative and entrepreneurial talents, the reform of teaching contents and teaching methods are carried out on the two subjects of the professional theoretical teaching curriculum system and practical curriculum system of colleges and universities, and the heuristic teaching and practical training teaching are carried out in depth. At the same time, Innovation and Entrepreneurship Discipline Contest Drives Vigorously the Construction of Three Platforms for Innovation and Entrepreneurship Training and Incubation of Innovation and Entrepreneurship Projects to Promote the Cultivation System of Innovative and Entrepreneurship Talents in Colleges and Universities[4][7]. The theoretical framework is shown in Figure 1.

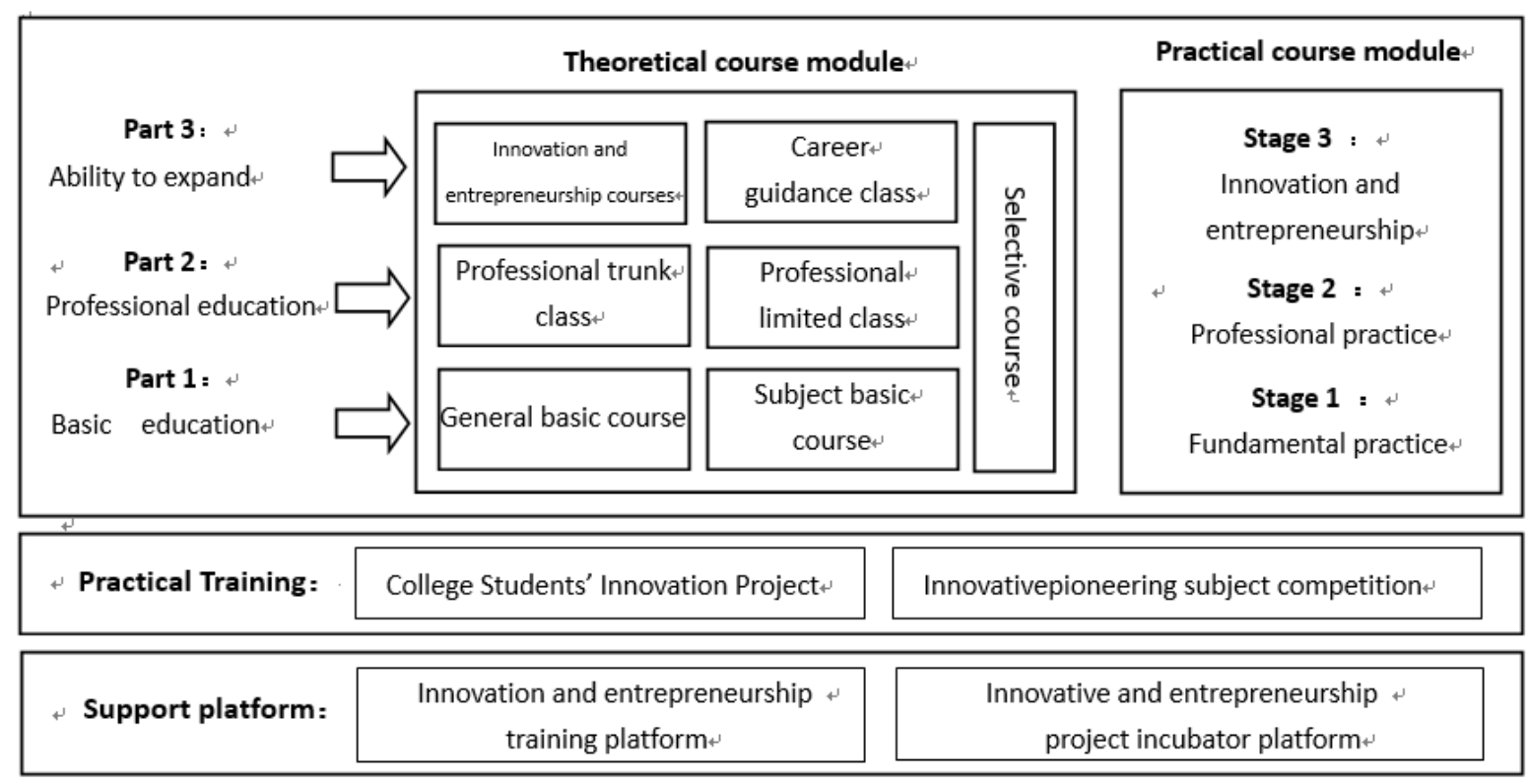

Figure 1.Training model of innovative pioneering talents in universities.

\section{Theoretical Course Module}

The concept of innovation and entrepreneurship education for college students should be transformed into educational practice. The key is the curriculum system. The module of theory course consists of general module, subject basic class, specialized backbone class, professional limited class and elective module of the whole school. The course is divided into three parts. The first part is basic education, which includes general basic course and basic subject course, basic course by subject type, solid basic discipline education, and lay a solid foundation for future professional choice of students. The second part is Professional education, according to the "fine professional, multi-directional" principle of professional education for students, select the content of 
professional courses, flexible setting of professional selection of curriculum modules for the students to choose the direction of the future to lay a solid foundation[2]. The third phase is the ability to expand course. Ability to expand innovation and entrepreneurship courses, career guidance courses, colleges and universities should integrate into multi-disciplinary education, multidisciplinary and multi-field development, focusing on broadening students 'knowledge, improve students' comprehensive ability, innovation and entrepreneurship[6].

\section{Practice Course Module}

Practice teaching system includes three kinds of practices: basic practice, professional practice and comprehensive practice. Through basic practice, students can improve their cognitive society, recognize the basic skills of professional and teamwork, and lay the foundation for professional study. Through professional practice, students' professional knowledge can be deepened. Students can acquire basic professional skills and methods and enhance their professional knowledge, Skills and skills. Through comprehensive practice, students should be trained to comprehensively use their knowledge to analyze and solve problems, improve their ability to adapt quickly to work positions, cultivate students 'comprehensive qualities, sense of innovation and entrepreneurship, stimulate students' motivation for innovation and entrepreneurship, and promote Students' scientific thinking, innovation awareness and ability to innovate, with the project as a guide, the combination of teaching and practice, targeted to strengthen the guidance of the process of student entrepreneurship.

\section{College Students Innovation and Entrepreneurship Projects}

Undergraduates Innovation and Entrepreneurship Project, also referred to as "DaChuang Project", is based on the principle of "grading organizations, interest-driven, process-oriented and cultivating achievements", and implements the management mode of the four-level project of colleges, schools, provinces and nationalities to establish innovative education for undergraduates Fund, to provide qualified scientific research project guidance, experimental sites and supporting funds, such as a full range of support[3]. The launching of innovation and entrepreneurship programs for undergraduates enables students to apply the theoretical knowledge and basic skills of innovation and entrepreneurship education in practice and accomplish the project research, competency training and achievement cultivation of entrepreneurial projects, and plays a positive role in driving the innovation and entrepreneurship training model in colleges and universities.

\section{Innovation Entrepreneurship Discipline Competition}

Innovation and Entrepreneurship Discipline competition so that students fully demonstrate their competitiveness in the competition, participating team spirit of cooperation. Each year's innovation and entrepreneurship competition will have some outstanding team come to the fore, the project into the incubator incubator for students to incubate the results of incubation. The holding of innovation and entrepreneurship contests at all levels has greatly stimulated the development of college students 'innovative and pioneering education. The students' willingness to innovate and start their undertakings has risen sharply and truly achieved the goal of "promoting education through race, promoting education through competition and promoting reform through competitions" Innovation and entrepreneurship training mode has played a positive role in driving.

\section{Innovation and Entrepreneurship Training Platform}

The innovation and entrepreneurship training platform for college students takes entrepreneurship project as carrier, entrepreneurial team as organizational form, through the simulation of 
entrepreneurship process in economic and social environment, entrepreneurial process taught in entrepreneurship education, entrepreneurship planning, entrepreneurship tools, entrepreneurial methods Simulation on specific projects, through the collaboration of team members and team confrontation experience the entire entrepreneurial process. Through practical training to improve students 'understanding of the market and control, cultivate students' innovative thinking and innovative awareness, improve their entrepreneurial quality, employment and entrepreneurship play a positive guiding role. At the same time, college students' innovation and entrepreneurship training platform provides a good project practice base for college students to participate in the innovation and entrepreneurship contest.

\section{Innovative Business Incubator Platform}

The incubator platform for college students' innovation and entrepreneurship projects is a base for innovation and entrepreneurship in colleges and universities. It provides entrepreneurship venues in the form of entrepreneurial parks and makes full use of the existing resources and social resources of schools as well as relevant government support policies to provide incubators for students with innovative and pioneering projects. Undergraduates' innovative and entrepreneurial practice, college students and their innovative and entrepreneurial teams are trained and enhanced in operations and management, capital operation, teamwork, public relations, risk competition, legal contracts, pioneering and innovation[9]. Students incubator platform for innovation and entrepreneurship to encourage innovative entrepreneurship student team settled.

\section{Tactics of Strengthening Innovative Talents Cultivation}

\section{Innovative Entrepreneurship Courses and Professional Courses In-Depth Integration}

In the education system into the innovation and entrepreneurship education, continue to improve students to master deep basic theory at the same time, training students innovative awareness and entrepreneurial ability to enable students to understand the quality requirements of innovative talents to understand the concept of entrepreneurship, elements, features, etc. to carry out entrepreneurial activities The basic knowledge required is to equip students with the necessary entrepreneurial skills through the cultivation of innovative and entrepreneurial qualities such as student insight, decision-making and organizational coordination[5]. Through reforming the course system and perfecting practice teaching, innovation and entrepreneurship education runs through the whole process of training innovative and pioneering talents.

\section{Incubation Students Outstanding Projects, Award-Winning Projects and Innovative Entrepreneurship Projects}

The incubator for students' innovation and entrepreneurship projects is based on the principle of "school hosting, market operation, centralized management, outstanding features and regional sharing" and encourages students with innovative ideas and entrepreneurship to move in. Through innovation and entrepreneurship training, enhance students' sense of innovation and entrepreneurship[8]. The incubator for students' innovation and entrepreneurship projects is based on the principle of "school hosting, market operation, centralized management, outstanding features and regional sharing" and encouraging students with innovative ideas and entrepreneurship to move in. Through innovation and entrepreneurship training, enhance students' sense of innovation and entrepreneurship[3].

\section{Carry Out Innovation and Entrepreneurship Exchange Activities}


The purpose of the innovation and entrepreneurship exchange activities is to enrich the students' experiences in innovation and entrepreneurship, to exchange ideas and innovations, and to learn from each other during the entrepreneurial process. Innovative entrepreneurship exchange activities in various forms, such as launching a business salon, a guest space, innovation and entrepreneurship forum.

\section{Conclusion}

The System of Cultivating Innovative Talents in Universities Introduces Elements of Innovation and Entrepreneurship in Higher Education Talents Cultivation and Fosters Students' Innovative Consciousness and Entrepreneurship. Curriculum set to professional theory teaching curriculum system and practice of curriculum reform and innovation as the mainstay, relying on innovation and entrepreneurship training and incubator project incubator two support platform to students innovation and entrepreneurship project and innovation and entrepreneurship competition as the driving force, innovation and entrepreneurship education Throughout the entire process of personnel training. The training model of innovation and entrepreneurship in colleges and universities is still under continuous exploration and remains to be further improved. Colleges and universities will play an important role in supporting outstanding innovative and entrepreneurial talents in the process of constant exploration.

\section{Acknowledgement}

This paper was the final research result of The Teaching Reform Research of Higher Education in Jilin Province “E-Commerce Major ‘the Three Innovations Talents’ Training Mode Research”. This research was supported by the Higher Education Institute of Jilin Province under grant No. JGJX2017D105 and No. JGJX2016D91, the support project of Philosophy and Social Sciences Planning Project of Changchun under grant No. CSKT2017ZX-0017, the support project of Jilin Department of Education "Thirteen Five" science and technology under grant No.JJKH20170122KJ, the support project of Jilin Province Education Science "Thirteen Five" Planning under grant No. GH170336, the support project of Jilin Province Education Science " Twelfth Five" Planning under grant No. GH150286.

\section{References}

[1] Qi L, Li Z , Li-fang P. Reflection on Training Model of Interdisciplinary E-commerce Talents ,J.Economy Management, 2007, (14):58-63.

[2] Yang L, Zhi W, Chun-yan Q, Exploration of “Sanchuang” Practice Teaching System in Colleges ,J.Modern Economy Information, 2017,(01):420-421.

[3] Yu-guang L, Xie-yong W . Innovation and Entrepreneurship Education Model of "Three Levels, Four Platforms” in Dalian’s Colleges J. China College Science, 2017,(21):102-104.

[4] Shuang-shou L, Yue-fei L, Hong-bin S, Bin Y. College Innovation and Entrepreneurship Training System Construction of “Trinity, Combination of Sanchuang” ,J.Education Research of Qinghua University,2017,38(02):111-116.

[5] Hui D, Xiao-mei Z . Deep Combination of Entrepreneurship and Innovation-Based on the Data Analysis of Colleges in BeijingJ.China College Science, 2017(05):91-94. 
[6] Gui-sheng S, Li-guo L. Research of Innovation and Entrepreneurship Talents Training-Based on The Beijing Joint University Department of Commerce,J. China College Science,2016(12):79-81.

[7] Xiang Y, Fu-rong X. College Innovation and Entrepreneurship Talents Training ConstructionJ. China College Science,2015(03):75-77.

[8] Wen-jing L. Research of Innovation and Entrepreneurship Talents Training of College Students J.China College Science,2016(12):82-84.

[9] Ying Z. Analysis of Innovation and Entrepreneurship Talents Training of College Students,J.China College Science,2016(12):90-91. 